\title{
Releitura da "mulher de bandido"
}

Ao homem que não me quis.

LEITE, Ivana Aruda.

Rio de Ja neiro: Agir, 2005. 87 p.

Ao que parece, há algumas décadas temos o que se pode chamar de sistema literário efetiva mente consolida do e ma is: há quem a fime que a inclusão feminina nessa ágora, como leitoras, críticas e produtoras, é plena. Sim, podemos considerar que o sistema literário brasileiro foi consolidado (salve Antonio Candido), mas a inclusão, independentemente das discussões relativas a gênero, é ainda uma sombra herdada de um passado confuso, desigual e violento.
Ivana Arruda Leite, a o lado de outras escritorascontemporâneas, presenteia esse nosso sistema consolidado com uma luz - a inda fraca - distinta do que o senso comum já se a costumou a chamar de literatura feminina. Eis as pilhas da lanterninha de Ivana: a autora trabalha com personagens mulheres, atuais, livres, emancipadas, bem resolvidas.

Mas não se iluda o leitor que esperar dos textos dela a perspectiva do sucesso absoluto, contrapondo a realidade atual com a problemática representação da figura feminina na literatura do passado (ops, na do presente ta mbém). Nem uma coisa nem outra. É impensável esperar de um texto de Ivana uma leitura agradável, doce, melosa, romântica, como é igualmente impensável esperarum texto político, comprometido com lemas de movimentos sociais, repetidos à exaustão e de modo equivocado poraí. 
Ao homem que não me quis, o ma is recente texto da escritora paulista, é um bom exemplo de como ela trabalha o tema. O mote do livro, que traz quinze minicontos e três contos, é a perspectiva que não podia ser mais realista $e$ atual: a domina ção masculina permanece, não menos forte, porém ma is disfa rça da. Ea releitura de personagens emblemáticas como Madame Bovary, em textos como o de Ivana ou de Clarah Averbuck (ma is jovem e ainda menos ligada a os clichês da literatura piegase melosa a tribuída à mulheres), torna-se necessária não para um reforço dos estereótipos geradores de preconceitos, maspara sutilmente evidenciarque o problema permanece.

Ivana abstrai os dois pólos perigosos: coloca-se à parte, num terc eiro caminho, a inda pouco explorado, quando se recusa a escrever como "mulherzinha" ou a levantarbandeiras. As personagens falam de si, sofrem, apanham, morrem de amor. Evocam vozes distintas, assumidas, corajosas, que gritam: foda-se tudo. As questões a qui trabalha das são huma nas, mas não deixam de ser extremamente femininas por conta disso. O minic onto "Por Deus", de apenas uma frase (abaixo), é bastante signific ativo:

Tira essa faca do meu peito e enterra o pau. É muito mais confortá vel.

Essa voz melancólica mistura uma submissão, evidente pelo tom clemente que o título e a primeira frase evocam, e desprendimento com a frugalidade e superficialidade da dor de amor, quando se coloca sexo em primeiro plano. Não é para seramada o que ela pede ao interlocutor invisível: é pau, sexo, gozo. Mais confortá vel no seu direito de ter voz, a mulheraqui pede o que melhor lhe parece.

Outros dois contos, dos maiores, seguem a mesma linha. Quem nos fala são vozes novas, sofridas, machucadas, mas vivas, confiantes e efetivamente maduras. "Da difícil vida das rêmoras" é um exagero. Narrado poruma mulher que ama um cafajeste confesso, o texto é anunciado pela epígrafe: "Todo exagero é mentiroso. A virtude está na linha do meio. Mas quem anda nela?". Logo nessa introdução, Iva na escla rece a o leitorque a inda espera uma tomada de partido que não há intenção de se alinhar com o que nos acostumamos a entender como certo. O conto é construído pela perspectiva intencional da vencida: uma mulher independente que luta, inclusive num cara-acara com uma rival, por um amorvagabundo. É ma is uma figuração do tipo "mulher de bandido", com uma diferença: não há vínculo com o estereótipo imposto pelo "sexo dominante" e o crime de se apaixonaré delibera do e assumido. Briga-se pelo direito a amaro que não é politicamente correto ou moralmente recomendável.

"Ao homem que não me quis", que dá título a o livro, conta a história de uma funcionária pública apaixonada porseu colega de trabalho, Lúcio. É importante se considerar, antes de qualquer coisa, que o "apaixonada" foi ina dequadamente aplicado. O que nosfazsupor qualquerdesc ontrole passional é, na verdade, o que move certo desejo da personagem. Paixão, sim, mas fruto de um capricho, de uma vontade quase somente física, sexual. 0 texto tem muito humor. Torna risíveis situa ções que deixariam alguns de cabelo em pé. É, enfim, um descompromisso com formas, conteúdos, perspectivas e tratamentos.

Ivana não tem medo. E, por isso mesmo, acaba por causar certas sensações de vitória um sentimento compartilha do de emancipação conjunta, social. Sim, somos mulheres, vamos conseguir vencer o preconceito! Mas atenção, leitor, não se iluda mais uma vez. Não há bandeiras levantadas aqui. Muito menos uma tentativa de erguê-las a todo custo. As mulheres de Ivana são deliberadamente auto-incluídas, plenas, seguras, inclusive para assumir fra queza s (antes liga das a o "sexo frá gil"). Não são a quelas atrizes sob holofotes intencionalmente guiados, mas a s próprias opera dora s de luz. São diretora s de a rte ou simples donas da lantema de plástico, herdada do pai ou do ex-marido. Senhoras de vozes conquistadas e eficazes para a abertura de um novo horizonte, um novo discurso, uma nova realidade.

Liana Aragão Universidade de Brasília 